\title{
The role of oil and gas in Kazakhstan's foreign policy: Looking east or west?
}

\section{Pinar İpek}

To cite this article: Pinar İpek (2007) The role of oil and gas in Kazakhstan's foreign policy: Looking east or west?, Europe-Asia Studies, 59:7, 1179-1199, DOI: 10.1080/09668130701607144

To link to this article: https://doi.org/10.1080/09668130701607144

册 Published online: 06 Jun 2008.

Submit your article to this journal $₫$

LIIl Article views: 1010

4 Citing articles: 21 View citing articles 


\title{
The Role of Oil and Gas in Kazakhstan's Foreign Policy: Looking East or West?
}

\author{
PINAR IPEK
}

\begin{abstract}
This study examines the role of oil and gas in the making of Kazakhstan's foreign policy. It argues that Kazakhstan has been following a multi-vector foreign policy in relation to its oil-led development and the geopolitics of exporting oil from this landlocked region. The significance of geopolitical considerations and the resulting pragmatism of Kazakhstan's leadership only allow a limited role for national identity and internal political dynamics in the making of its foreign policy. Kazakhstan's geopolitical imperatives force the country to keep good relations with Russia and China as well as with the US and the EU, as counterbalancing partners.
\end{abstract}

FOLLOWING THE INAUGURATION IN DECEMBER 2005 OF an oil pipeline running from Atasu, located in north-western Kazakhstan, to Alashankou, in China's north-western Xinjiang (Eastern Turkestan) region, there have been growing concerns about Kazakhstan's foreign policy orientation and its increasing cooperation with China. Despite the long-sought agreement between Kazakhstan and Azerbaijan in June 2006 to transport increased production from the offshore Kashagan field of Kazakhstan to the Baku-Tbilisi-Ceyhan (BTC) pipeline, substantial talks on building a sea-bed pipeline to connect Kazakh oil to this pipeline are on hold. Rather, Kazakhstan will transport oil from Aktau to Baku by existing tankers and a new large-capacity tanker fleet. Thus, the reluctance of Kazakhstan to build a trans-Caspian pipeline has fuelled concerns over whether Kazakhstan is looking East or West. ${ }^{1}$

Foreign policy making is influenced by numerous domestic and international factors. In Kazakhstan, for example, a wide range of determinants should be assessed in terms of their influence on foreign policy. These include the nature of the regime in its post-Soviet state-building process; questions of national identity; the influence of domestic groups, especially clans, on government policy; Kazakhstan's landlocked geography; the interests of neighbouring powers; and the investment of multinational corporations (MNCs) in the rich oil and gas. Above all however, it will be argued here, the questions of under what conditions and to what extent Kazakhstan's oil and gas

The author would like to thank the two anonymous reviewers for their comments on an earlier draft of this article and Hasan Ali Karasar and Paul Williams for their help in revising the article.

${ }^{1}$ The trans-Caspian pipeline has been planned to be built underwater from the port of Kirik located $76 \mathrm{~km}$ from Aktau, Kazakhstan, to the Azerbaijani terminal at Dyunbendi, near Baku. 
resources are determinant in foreign policy making are crucial to this study. The argument suggests that Kazakhstan has been following a multi-vector foreign policy in strict relation to oil and gas contracts, given the determining influence of geopolitics and the pragmatism of the Kazakh leadership in its foreign policy discourse.

The article will first demonstrate how geopolitics has prevailed by examining the connections between the demarcation of the Caspian Sea, priorities in oil and gas agreements and the pragmatism of President Nazarbayev. Second, the role of neighbouring powers, namely Russia and China, as well as the United States, in pipeline projects will be incorporated into the analysis to highlight how the multivector foreign policy has been enforced by the Kazakh leadership's pragmatism and the landlocked geography. Third, the relative weakness of domestic politics will be discussed in relation to the making of foreign policy in Kazakhstan.

\section{Economic crisis, dependence on Russia and pragmatism: tactical concessions to Russia}

Since Kazakhstan's independence in 1991, its experience has been considerably different from those of other former Soviet republics due to its geographic location and demographic composition. Kazakhstan is the only Central Asian state sharing a long border with Russia, and its large ethnic Russian population continues to reinforce Kazakhstan's cultural and historical ties to Russia. ${ }^{2}$ Because of its function in the collapsed Soviet economic and political system, the Kazakh economy had been focused on the extraction and production of raw materials. However, the break-up of inter-republic integration following the dissolution of the Soviet Union had a devastating effect on the Kazakh industrial sector, which had been tightly enmeshed in the Soviet economic exchange system. Thus, the severe economic crisis after the collapse of the centralised Soviet economic system impelled the Kazakh leadership to pursue a hydrocarbon-based path to economic development by attracting foreign direct investment in the oil and gas sectors.

Nursultan Nazarbayev, the leader of Kazakhstan's Communist party under Gorbachev, was elected as the first president of the independent Republic of Kazakhstan on 1 December 1991. He advocated gradual economic reforms that would not disrupt the existing political order even after the demise of the Soviet Union. Despite Nazarbayev's strong desire for economic sovereignty, he was also highly reluctant to leave Russia's sphere of influence. Several factors determined the Kazakh political leadership's relative dependence on Russia. First, Kazakhstan's industrial enterprises were tightly integrated into the Soviet economic system. Kazakhstan's oil and gas enterprises were particularly vulnerable in this respect. ${ }^{3}$ In fact, though rich in oil and gas reserves, Kazakhstan was practically dependent on existing supplies of oil from Russia and gas from Uzbekistan. In 1994, energy accounted for as much as $32 \%$

\footnotetext{
2،According to the last Soviet census, taken in 1989, Kazakhs constituted $39.5 \%$ of the population, while Russians were $37.7 \%$. Combining Russians with the Ukrainians (5.4\%) and the Belorussians $(1.1 \%)$, the Slavs constituted $44.2 \%$ of the population, when also combined with the largely Russified Germans (5.8\%), non Kazakhs formed a bare but absolute majority in the republic' (Cummings 2003, p. 145).

${ }^{3}$ UN Industrial Development Organisation (1996, p. 12); Economist Intelligence Unit (1997, pp. $10-$ 27).
} 
of Kazakhstan's total imports (World Bank 1994). Furthermore, the oil and gas extracted in Kazakhstan had usually been sent for processing to Russia, while Kazakhstan's own oil refineries (Pavlodar, Chymkent and Atyrau) mainly processed Siberian crude. The first two refineries were located in eastern Kazakhstan and $75 \%$ of their inputs were supplied by Siberian crude, leaving Atyrau as the only refinery supplied completely by Kazakh crude (Economist Intelligence Unit 1998).

Secondly, ethnic Russians, comprising almost half of Kazakhstan's population in the early years of independence, predominantly inhabited the north-western part of the country along the Russian border, and their separatist inclinations presented a potential threat to Kazakhstan's territorial integrity (Olcott 2002, pp. 51-87; Savin 1998; Schatz 2004, p. 101). Finally, lacking in trained military personnel and technology, Kazakhstan also depended on the Russian army for protection of its long border with China, also perceived as a potential threat to Kazakhstan's security in the early years of independence. ${ }^{4}$ In fact, cognisant of these realities, Kazakhstan was the last among the Soviet republics to declare independence on 16 December 1991. Quickly thereafter, on 21 December 1991, Kazakhstan joined the Russo-centric Commonwealth of Independent States (CIS). Kazakhstan's dependence on Russia was magnified by the lack of adequate pipeline infrastructure to generate sufficient oil revenues to boost its economic recovery. Therefore, Kazakhstan had to export its oil through Russian territory via Russian-controlled pipelines. Olcott (1995) has explained the dependence of Kazakhstan on Russia as follows:

The state is landlocked, more remote from open ocean than is any other large nation of the world, and hence more dependent on its neighbours to be both customer and vendor. It is also demographically vulnerable, almost equally split between two ethnic groups whose interests, desires, and cultures are all but antithetical; what is worse, ... Kazakhstan also shares an enormous and undefendable border with Russia, which would no more permit Kazakhstan to become a strong independent military power... Kazakhstan knows perfectly well that, at least in its own case, there is no realistic way that Russia can be cut out of the Caspian oil profits, because it is too easy for an excluded Russia to ensure that no one else can have the oil, either pipeline or no pipeline.

Within this framework, President Nazarbayev had no alternative to pragmatism in foreign policy making (Cummings 2003, p. 139; Bukkvoll 2004, pp. 637-41). The pragmatic character of Kazakhstan's foreign policy is exemplified by the dispute that took place over demarcation of the Caspian Sea. The dependence on Russia on the one hand, and the need to attract large volumes of foreign direct investment into oil and gas sectors on the other hand, demanded a flexible foreign policy capable of meeting the dual challenges of state-building and economic recovery in the early years of independence. Kazakhstan favoured the demarcation of the Caspian Sea into national sectors over which each state had exclusive sovereignty. Russia and Iran, however, contended that the Caspian is actually an inland lake and thus subject to joint control by all littoral states. The other two littoral states, Azerbaijan and Turkmenistan, shared Kazakhstan's interest in national sectors.

\footnotetext{
${ }^{4}$ Author's interview with two diplomats in the Ministry of Foreign Affairs, 22 February 2002, Astana, Kazakhstan.
} 
Russia argued that historic treaties with Iran in 1921 and 1940 implied that the sea could not be divided (Croissant \& Croissant 1999, pp. $21-42$ ). ${ }^{5}$ Although Kazakhstan was not a party to these treaties, the Alma Ata Declaration of December 1991, that established the Commonwealth of Independent States (CIS) and was signed by all the former Soviet Republics, included a specific proviso recognising the validity of all treaties and agreements signed by the USSR. There was, therefore, a legal basis for keeping the treaties between Russia and Iran in force. Russia considered the region to be under its sphere of influence by virtue of its historic role as a colonising power and as a former superpower. Thus, Russia claimed to have certain rights in Kazakhstan because industries were developed there by means of Russian financial support and expertise. The mind-set was that 'Russia must have access to the resources of the CIS. We, by virtue of our labour, mind, and energy, have created all this' (Schofield \& Pratt 1996, p. 77). Another reason for Moscow's interest in maintaining economic influence in the Caspian region was its desire to protect its own internal security. Many of Russia's southern regions have significant Muslim populations. Therefore, Russia was concerned that if Kazakhstan showed it was able to defy Moscow's control completely, Muslim independence movements would spread into Russia.

While Turkmenistan, Azerbaijan and Kazakhstan have significant Caspian oil and gas reserves in their national sectors, Russia and Iran have relatively small reserves. Both Russia and Iran had the option of slowly developing oil resources located in other regions of their territories. By contrast, accelerated production was important for Kazakhstan to stabilise its economy and to consolidate President Nazarbayev's power by generating revenues from oil exports. Thus, a pragmatic foreign policy to develop its offshore oil and gas resources freely, with the active participation of Western oil firms and governments, was crucial to overcoming the dual challenges of state-building and economic recovery in this landlocked country. From the beginning, President Nazarbayev's pragmatism took a very careful position in relation to Russia. In contrast to Azerbaijan's proven offshore fields, the Kazakh section of the Caspian Sea had never been explored before. The Kazakh government lacked complete information on the potential reserves located in the North Caspian Sea until 2002-03. Thus, President Nazarbayev did not want to escalate difficulties with Moscow while the country was considerably dependent on Russia in the early 1990s. Kazakhstan started to pursue a more active policy to strengthen its rights on the Caspian Sea only at the beginning of 1994, when Western oil companies launched an ambitious project aimed at exploration and extraction of potentially the largest reserves in the Kazakh section of the Caspian Sea. ${ }^{6}$

\footnotetext{
${ }^{5}$ The Treaty of Turkmanchai (21 February 1828) established that the land boundary between Russia and Persia would end at the Caspian Sea, thus implying that the sea was not subject to delimitation at the time. Article 8 of the treaty also established freedom of navigation on the Caspian for merchant vessels of both sides, but reserved for Russia the sole right to deploy warships there. The SovietPersian Treaty of Friendship (26 February 1921) established freedom of navigation for all Soviet and Persian ships on the Caspian. The Treaty on Trade and Navigation between the USSR and Iran (25 March 1940) reiterated the freedom of navigation rights of the 1921 treaty. Moreover, a 10-nauticalmile offshore fishing zone was recognised.

${ }^{6}$ The Offshore Kazakhstan International Operating Company (OKIOC) was formed in September 1998 to explore the Caspian shelf under a production sharing agreement signed in Washington in
} 
The issue of demarcation of the Caspian Sea illustrated a delicate diplomatic manoeuvre highlighting the pragmatism in Kazakh foreign policy in exerting its offshore territorial rights while still acknowledging the overall superiority of Russia's position. Kazakhstan chose a strategy of tactical concessions in pursuing its multi-vector foreign policy. In 1996 it gave the impression, through then Foreign Affairs Minister K. K. Tokaev's visit to Moscow, of Kazakhstan's readiness to support the Russian position against Azerbaijan. However, the Western oil companies that were engaged in the exploration of the north Caspian shelf, through their membership of the Offshore Kazakhstan International Operating Company (OKIOC), were supportive of dividing the Caspian Sea into national sectors. Russia made a goodwill gesture and proposed a new policy for the Caspian in November $1996 .{ }^{7}$ Accordingly, Russia would accept national sectors and exclusive economic zones within certain limits, beyond which there would be a large section under the common jurisdiction of the five littoral states. All Caspian littoral countries except Azerbaijan and Kazakhstan signed the proposal. President Nazarbayev, recognising that this proposal would benefit Russia more and possibly constrain the economic independence of Kazakhstan, withheld consent.

The two major oil production fields in Kazakhstan were Tengiz and Karachaganak, both at some distance from the Caspian. Unlike Azerbaijan, therefore, Kazakhstan did not have an immediate stake in the demarcation of the Caspian Sea. Moreover, Kazakhstan struggled with its aforementioned dependency dilemma vis-à-vis Russia, particularly in terms of exporting its oil. While the main challenge for Kazakhstan has long centred on how to decrease its dependence on the Russian-controlled pipeline system, the full development of its enormous oil fields required time and capital to build infrastructure. Therefore, Kazakhstan gradually had to pursue a Western orientation in its foreign policy. In fact, since the signing of the first oil contract, Nazarbayev had always offered Russian firms and the Russian government the opportunity to actively participate in the rebuilding and reconstruction of its industry. Consequently, a geopolitically enforced pragmatism limited the ability of Kazakhstan to counterbalance Russian interests in the issue of demarcating the Caspian Sea, particularly in the early years after independence.

\section{Geopolitics of oil and gas and multi-vector foreign policy: an evolving relation with the West}

Following Kazakhstan's dependence on Russia in the early years of its post-Soviet independence, its geopolitical situation gradually changed so that the priority shifted to a need to balance the interests of Russia, China, and the United States.

November 1997. Italy's Agip, British Gas (BG), Shell, a BP(UK)/Statoil (Norway) alliance, Mobil (US), Total (France) and Kazakhstan's KazakhCaspiShelf founded the consortium, each with a one-seventh interest. KazakhCaspiShelf sold its stake to Inpex Nord Ltd of Japan and Phillips Petroleum of the US in the autumn of 1998. British Gas also decided to sell its $16.7 \%$ share of the field. Only recently after drawn-out negotiations, consortium members decided to redistribute BG's share, giving half to themselves and half to Kazmunaigaz. As of May 2006 the consortium members of Agip Kazakhstan North Caspian Operating Company (Agip KCO) (formerly OKIOC) are: Agip (operator), Total, ExxonMobil and Shell (18.52\%), ConocoPhillips (9.26\%), Kazmunaigaz (8.33\%) and Inpex (8.33\%).

${ }^{7}$ For a discussion of Russian 'involuntary disengagement' see Jonson (1998, pp. 6-25 \& 69-75). 
When it became clear that Russia did not have sufficient financial clout and technology to develop the huge oil resources in Kazakhstan, Nazarbayev turned to the major Western oil companies. His main strategy was to diversify sources of funding to safeguard economic stability during the state-building process and consolidation of his power. He noted that

the investment potential of Kazakhstan is so large that it would require resources which are not available even to the highly developed countries. Thus, the requirement for a diversified set of investors that represents dozens of countries from Europe and Asia in addition to the US is an imperative in Kazakhstan's policy. ${ }^{8}$

A senior government officer in the state oil company Kazakhoil explained the preferences of the Kazakhstan government as follows:

the government first wanted Tengiz and Karachaganak to be finalised. These fields have proven reserves. So, we could start production and exporting as early as possible. That was a priority for the contracts. The Kazakh economy needed its oil and gas sector to be developed... There were large companies from large Western countries. These countries would not allow the change of the political situation in Kazakhstan. So it was good for the Kazakh government. All companies from Russia and China were also invited in all tenders. In 1997 the CNOC (Chinese National Oil Company) for example won the tender for Aktobe. Lukoil was in Kazakhstan before for Caspian Pipeline Consortium (CPC) and Karachaganak oil field. ${ }^{9}$

In his turn to the West, President Nazarbayev was able to establish extensive diplomatic relations with the US government because it was one of four states in the former Soviet Union that had nuclear weapons and facilities. In May 1992, shortly after Kazakhstan had declared its independence, Nazarbayev was invited to the White House to agree on early ratification and implementation of the Strategic Arms Reduction Treaty (START) (US Department of State 1992). The US government gave priority to the establishment of an effective national control in Kazakhstan over the non-proliferation of weapons of mass destruction and associated technologies to other countries. ${ }^{10}$ In December 1993, Kazakhstan endorsed an international treaty to halt the spread of arms and signed an agreement to dismantle its nuclear arsenal during the visit of US Secretary of State Warren Christopher and Vice President Al Gore to that country. Following the agreement, the assistance pledged to Kazakhstan by the Clinton administration increased from \$90 million in 1993 to \$300 million in 1994 (Berke 1993). Thus, Kazakhstan could obtain economic assistance from the US government by complying with the Non-Proliferation Treaty and dismantling its nuclear weapons safely. In a local interview after his first visit to the White House in

\footnotetext{
${ }^{8}$ Nezavisimaya Gazeta, 28 April 1998.

${ }^{9}$ Author's interview with a senior officer at Kazakhoil, Division of External Economic Affairs, 20 February 2002, Astana, Kazakhstan.

${ }^{10}$ For example, Kazakhstan had an estimated 1,410 warheads and 104 SS-18 intercontinental ballistic missiles (Smith 1992). In November 1997, an agreement was signed between the US and the Kazakhstan governments on the safe disposal of nuclear material from the Aktau reactor; and the US government pledged $\$ 10$ million to help improve security at the storage site, which was located some 200 miles from Iran (Associated Press, 18 November 1997).
} 
February 1994, President Nazarbayev emphasised the importance of economic assistance to Kazakhstan by the US government and multilateral agencies such as the IMF and World Bank:

It was very important for us to establish political and economic relations, and to enlist the support of the USA at a difficult time. Moreover, I was grateful because the USA actively supported us, so that the donor states should help Kazakhstan with advantageous credits for supporting our currency and our reforms [referring to the IMF and the World Bank]. I think we managed to achieve a high level of mutual understanding and trust in this, both with President Clinton and with Vice-President Gore. ${ }^{11}$

In fact, the economic assistance of the multilateral agencies was critical for the Kazakhstan economy, given its negative growth rate between 1993 and 1995 and the delay in exporting oil from Tengiz field via the CPC. ${ }^{12}$

Thus, Nazarbayev followed a pragmatic course in seeking to ensure economic stability via the economic assistance of multilateral agencies backed by US government support, through investment from big Western oil firms, and by cultivating a strategic partnership with Russia. This reinforced a multi-vector foreign policy in strict relation to the salient geopolitical context of the oil and gas contracts. Kazakhstan was dependent on the Russian pipeline system to transport oil from its landlocked territory and it needed to infuse its economy with hard currency to secure stability in the early years after independence. Accordingly, the large Western firms with enormous capital and technological resources were essential to the economic stability of Kazakhstan. (In fact, there were no small firms involved in Kazakhstan's major oil projects for developing Tengiz and Karachaganak.) A Kazakh officer in the Ministry of Energy explained the importance given by the government to the large size of a firm to facilitate oil exports and economic recovery as follows:

The government first tried to sell Tengiz and Karachaganak. They tried to sell these fields to big companies. We wanted to produce and export oil as early and as much as we could. Our economy was not in good condition. Big companies were preferred because they have the large finances, high technology, and experience to start quickly. We wanted all types of companies, but these fields were a priority and we wanted big companies for these fields. ${ }^{13}$

The first oil contract signed by Kazakhstan was for the Tengiz onshore field, the largest proven onshore field in a former Soviet republic. ${ }^{14}$ As a result, Tengizchevroil, a joint venture between the US company Chevron and the Kazakhstan government, was established in April 1993. Although the Soviet Union had begun to develop the field, the existing Soviet technology was not capable of fully exploiting the reserves. ${ }^{15}$

\footnotetext{
${ }^{11}$ 'Nazarbayev says USA will Help Kazakhstan if Borders Threatened', BBC Summary of World Broadcasts, 22 February 1994, available at: http://web.lexis-nexis.com/universe, accessed August 2002.

${ }^{12}$ For Kazakhstan's economic growth see Pomfret (2005).

${ }^{13}$ Author's interview with a specialist in production sharing agreements at the Ministry of Energy and Mineral Resources, Department of Oil Industries, 20 February 2002, Astana, Kazakhstan.

${ }^{14}$ The Tengiz oil field is the largest oil discovery in the world since the 1970s, with proven highquality reserves of $6-9$ billion barrels.

${ }^{15}$ The oil in the Tengiz field is located very deep, at a high temperature and pressure, with high hydrogen sulphide content, making it relatively expensive to extract and refine.
} 
Tengizchevroil was a good illustration of the constraints stemming from Kazakhstan's dependence on Russia and the willingness of Russia to influence the Caspian region by controlling pipeline routes. During the Soviet era, all oil and natural gas pipelines in the region were designed to link the Soviet Union internally and were routed through Russia. Prior to 1997, the only major pipeline in the region was the Atyrau-Samara pipeline from Kazakhstan to Russia (Energy Information Administration 1997). In the early phases of production in major oil fields, smaller amounts of oil were exported by barge and by rail through Russian territory. With larger production coming online, Kazakhstan needed new routes to transport Caspian oil and natural gas to world markets. Major pipelines passing only through Russian territory would give Russia monopoly power and dominant political influence over Caspian countries, neither of which Kazakhstan or the oil MNCs wanted to see. However, the full development of its enormous oil fields required time and capital to build adequate infrastructure, which in turn did not allow Kazakhstan any option but to continue its strategic partnership with Russia.

Problems with the export of Kazakh oil started when Russia began to complain about the presence of mercaptans, sulphur compounds, found in Kazakh oil. Although under the Soviet system officials did not object to the same mercaptans, post-Soviet Russian authorities now claimed they had to limit Tengizchevroil's access to the Atyrau-Samara pipeline until the situation improved (LeVine 1994). In March 1993, the Russian government signed an agreement with Chevron and the Kazakhstan government to allow Tengizchevroil to export a certain number of barrels per day, with an option to increase the quota once the mercaptan problem was eliminated. Chevron duly invested $\$ 100$ million in technology to remove the mercaptans from the oil, and the technology has been functional since the end of 1994 (Petroleum Finance Company 1993, pp. 21-22). Nevertheless, Russia did not consistently permit Tengizchevroil to export even the agreed quota. ${ }^{16}$ In 1995 Chevron almost cancelled the project and stopped its projected investment.

Meanwhile, prior to the Tengiz agreement, Russia, Kazakhstan and Oman had formed the CPC in 1992 to build a pipeline for the transportation of oil from the Caspian region to Novorossiysk in the Black Sea. ${ }^{17}$ Kazakhstan's contribution to the project was to be a combination of territory and oil while Oman was expected to finance most of the project. The CPC's original plan was to finish construction of the existing infrastructure that had been $60 \%$ completed during the Soviet era. However, Oman could not meet its financial obligations. From 1992 to late 1994, Russian officials tried to persuade Chevron to provide most of the financial support in exchange for a $25 \%$ non-decision-making equity share (Forsythe 1996, p. 49). During this period, Russia did not allow Chevron to export through the Russian-controlled existing pipeline, the only export outlet of Tengizchevroil, in a regular manner

\footnotetext{
${ }^{16}$ Chevron, company press release, 18 July 1995.

${ }^{17}$ Russia's President Boris Yeltsin and Kazakhstan's President Nursultan Nazarbayev signed a protocol on the construction of the CPC on 27 April 1996 (Thoenes 1996b). The final agreement was signed between eight oil companies and three governments on 6 December 1997. The stakeholders were as follows: Russia (24\%); Kazakhstan (9\%); Oman (7\%); Chevron (15\%); Lukoil (12.5\%); RosneftShell (7.5\%); Mobil (7.5\%); Agip (2\%); British Gas (2\%); Kazak Munaigas (1.75\%); and Oryx $(1.75 \%)$ (Freeland \& Thoenes 1996).
} 
(Thoenes 1996d). In January 1995, Russia and Dutch financier John Deuss, the chairman of the Omani Oil Company, imposed a new administrative structure that decreased Kazakh control over pipeline quotas and fees. Chevron refused the unattractive terms of the new agreement, since it would give the firm less decisionmaking power than its Russian partner and John Deuss. In April 1996 John Deuss, who insisted on restructuring the agreement, opted out of the CPC project.

Moreover, also in April 1996, Mobil (US) bought half of Kazakhstan's 50\% share in the Tengizchevroil project. Most analysts agreed that Mobil's purchase brought about a positive resolution to the export issue, since President Nazarbayev was aiming to balance Russian pressure with US government support (Thoenes 1996a). At the same time, Russian oil firm Lukoil reached a preliminary agreement with the Kazakhstan government for the purchase of part of Kazakhstan's remaining stake in Tengizchevroil. Lukoil's share in Tengizchevroil was funded primarily by Lukoil's strategic partner Arco (US). ${ }^{18}$ According to industry resources, President Nazarbayev wanted to secure export of Karachaganak's oil and gas to avoid similar problems to those experienced by Tengizchevroil (LeVine \& Curzine 1994). So, in February 1995 Kazakhstan brought the Russian oil firm Lukoil into the Karachaganak project. ${ }^{19}$

As well as maintaining good relations with Russia, which controlled the easiest and least expensive pipeline routes, Kazakhstan's multi-vector foreign policy emphasised building relations with China, with its rapidly growing demand for energy. Accordingly, the Kazakh government pursued a strategy of inclusion toward Russia and China, in contrast to Azerbaijan's clearly exclusive preferences for Western companies. ${ }^{20}$ A government official in the state oil company, Kazakhoil, ${ }^{21}$ illustrated this inclusion strategy of the government with the following example: 'The Chinese National Company (CNCP) gave the offer for Aktobe field and got it. The government tried to include Russia and China... All companies from Russia and China were also invited in all tenders'. ${ }^{22}$ President Nazarbayev explained the inclusion strategy of Kazakhstan's foreign policy at a press meeting at the National Press Club, in Washington, DC, in May 1992, during his first visit to the United States:

Our foreign policy is very much oriented to the geopolitical position of Kazakhstan. In the south, apart from the former Soviet Central Asian states, we've got such countries as India, Iran, Pakistan, and Afghanistan. In the east, we've got 1,500 kilometres of common frontier with China. In the north, we border Russia. I adhere to the policy of integration within the Commonwealth, and I'm doing everything possible so that the further disintegration of the Soviet Union continues without any bloodshed or further clashes. We will try to strategically continue building a good relationship with Russia, coordinating all of our problems as well as

\footnotetext{
${ }^{18}$ Petroleum Finance, 5 May 1997.

${ }^{19}$ In 1997 Lukoil signed a production sharing agreement with AGIP, BG, and the Kazakhstan government.

${ }^{20}$ For details of Azerbaijan preferences see Ipek (2004).

${ }^{21}$ The national companies of Kazakhoil and Transportneftigaz (TNG) merged into a single closed joint-stock company called KazMunaiGaz (KMG) National Company by a Presidential Decree, signed in February 2002.

${ }^{22}$ Author's interview with a senior officer at Kazakhoil, Division of External Economic Affairs, 20 February 2002, Astana, Kazakhstan.
} 
our work in economics and politics - the same good relationship we are building with our traditional neighbour, China. ${ }^{23}$

After achieving much needed economic recovery, new pipelines bypassing Russia to secure economic independence became the long-term strategic goal of Kazakhstan's multi-vector foreign policy. The government of Kazakhstan did not have an exclusive commitment to a Western route for its export outlets. The Kazakh government's policy made it a priority to export oil from any route feasible in the shortest possible time. Thus, they delayed a final decision on a major export pipeline, in contrast to Azerbaijan's early commitment to a Western route, namely between Baku and Ceyhan (in Turkey), that would bypass Russia. In fact, President Nazarbayev has been very consistent in highlighting the priorities of Kazakhstan's foreign policy to be the maintenance of good relations with Russia, China, and the United States, in various statements made throughout his presidency. ${ }^{24}$ An American oil company officer explained the position of Kazakhstan as follows:

Kazakhs were more close to Russian influence. Russia and Kazakhstan had a five-year transportation of oil agreement. Offshore fields were also later on the table. The Kazakh government was pretty consistent in directing companies first to Tengiz then to other onshore fields and later to North Caspian offshore blocks. They wanted oil to be produced and exported as quickly as possible.... For example, Iran was a problem for transportation of oil from big oil consortiums in Kazakhstan. Agip was chosen for operatorship in OKIOC [the largest consortium to explore and produce oil in offshore fields of the Northern Caspian Shelf of Kazakhstan] since it is a European company. European companies provide access to TACIS money and no sanctions for transportation of oil through anywhere for them. ${ }^{25}$

Within this framework, one could observe a careful balancing act between Russia, China, and the United States in Kazakhstan's foreign policy that was strictly related to the geopolitics of exporting oil out of this landlocked region. While Kazakhstan has had a persistent policy of enticing large Western companies to invest in its oil and gas sector, balancing the strategic partnership with Russia in the CPC pipeline and the long-term goal of new pipelines bypassing Russia required a multi-vector foreign policy. The early extensive diplomatic relations established with the US government, given the nuclear weapons and facilities in Kazakhstan, helped to maximise its national interests and to balance its dependence on Russia and the influence of China.

Following the progress on Tengiz and Karachaganak fields and rapidly growing revenues due to high oil prices, Kazakhstan has gradually consolidated its power over the foreign oil firms in the past three years (Buckley \& Hoyos 2005) (see Table 1). ${ }^{26}$ For example, The Kazakh government wants the state oil company, KazMunaiGaz,

\footnotetext{
${ }^{23}$ 'National Press Club Afternoon Newsmaker, President Nursultan Nazarbayev of Kazakhstan', Federal News Service, 20 May 1992.

${ }^{24}$ 'Kazakh Uses America to Enhance His Stature', New York Times, 25 October 1993, p. A2; Corzine (1997); Kononovich (2004); Kazakhstanskaya Pravda, 19 February 2005.

${ }^{25}$ Author's interview with an ex-officer of Mobil on 29 January 2002, in Almaty, Kazakhstan.

${ }^{26}$ 'Kazakhstan's Economy: The Pushy Partner', Alexander's Gas and Oil Connections, 10, 21, 10 November 2005, available at: http://www.gasandoil.com/goc/history/welcome.html accessed 17 May 2006.
} 


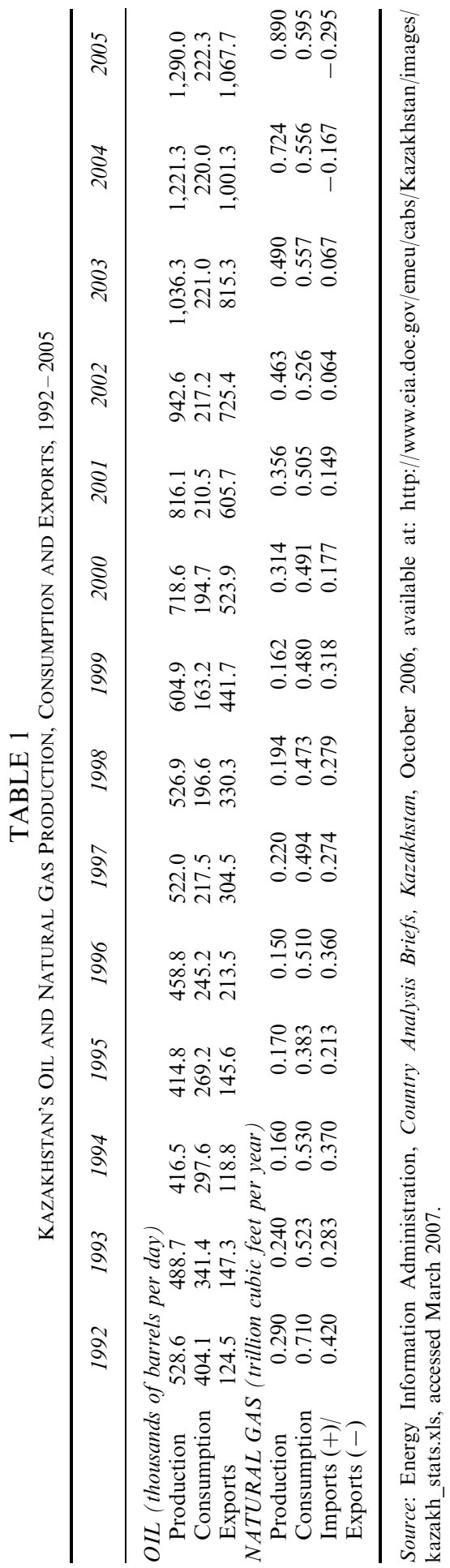


to have a larger role in the country's production as well as to increase its revenues by the introduction of a new tax regime. ${ }^{27}$ Accordingly, the Kashagan field, the biggest offshore oil discovery anywhere in the world in the last 30 years, has had a decisive influence on the competition among Russia, China, and the United States over which pipeline would receive the bulk of Kazakh oil. Although it is clear that the country will produce more oil for daily export than Iran in the next decade, little progress has been made on an alternative pipeline route to Western markets. The competition over exporting future increased oil production thus facilitates the multi-vector policy of Kazakhstan.

In this sense, improving relations with China have not come at the expense of strategic partnership between Kazakhstan and Russia. China is determined to secure oil supplies and develop relations with Kazakhstan. ${ }^{28}$ For example, in addition to the completion of the Kazakhstan-China pipeline running from north-western Kazakhstan to China's north-western Xinjiang region, China National Petroleum Company/ Corporation (CNPC) bought former Canadian firm PetroKazakhstan for what some argued to be an excessively high price. ${ }^{29}$ While China sees Kazakhstan as a safe source of oil, the perception by the Kazakh public of Kazakh-Chinese relations reflects a mixture of fear and suspicion (Gorst \& Tsui 2005; Thoenes 1996c; Yermukanov 2004, 2005a). In fact, the Kazakh government has ensured that control remains with the state national oil company, KazMunaiGaz, by increasing the stakes of this company in the PetroKazakhstan agreement with CNPC (Blank 2005). Despite political sensitivities in Kazakhstan on the subject of allowing a Chinese company to own strategic oil assets very close to their countries' common border, President Nazarbayev chose the Kazakhstan-China pipeline as an extra oil export route to reduce its dependence on Russia.

Furthermore, heightened fears about energy security in the aftermath of hurricane Katrina, China and India's emergence as major energy importers, the dispute between Russia and Ukraine, the war in Iraq, the nuclear threat by Iran and the consequent uncertainty in the Middle East facilitates the balancing act in Kazakh foreign policy. In light of high oil prices, Kazakhstan has gradually consolidated its power over foreign oil firms. However, Kazakhstan's new tax regime and regulations on foreign direct investment, aiming to increase national control and revenues from oil output, have diminished the willingness of major oil MNCs to invest in field development and exploration of new offshore blocks. For example, there has been slow progress in the

\footnotetext{
${ }^{27}$ For example, KazMunaiGaz must now own at least half of any PSA and will act as contractor in all new offshore PSAs in Kazakhstan. Also, the introduction of a new tax structure in January 2004 included a so-called 'rent tax' on exports, a progressive tax that increases as oil prices grow. The new amendment to Kazakhstan's tax law has raised the government's share of oil income to a range of $65-$ $85 \%$, and it has removed a clause guaranteeing investors a static tax rate throughout the duration of the contract. The new structure includes an excess profit tax, and limits foreign participation to $50 \%$ in each offshore project with no guarantees of operatorship. The other $50 \%$ will belong to KazMunaiGaz.

${ }^{28}$ For China's energy policy, see Zweig and Jianhai (2005).

${ }^{29}$ The Aktobe field in the northwest, which the CNPC acquired in 1997 and the Kumkol field that the CNPC bought from PetroKazakhstan in March 2006 will feed oil to the Kazakhstan-China pipeline. Initially, half the oil pumped through the new pipeline will come from Russia because of insufficient early output from these fields.
} 
Kashagan offshore field's development, thereby possibly delaying the start of production beyond 2008. ${ }^{30}$ In addition to Kazakh government pressure to use local supplies, difficult weather conditions and technological hurdles have slowed the development of the project. Nevertheless, despite increasing leverage of the Kazakh government on foreign investors, China has been keen to overpay for any equity oil it can find. ${ }^{31}$ Therefore, President Nazarbayev has been comfortable pursuing strategic partnerships with Russia, China, and the United States.

Several other factors, related to the geopolitics of exporting oil out of this landlocked region, also require balancing the interests of Russia, China, and the United States. First, although the US government was a strong advocate of trans-Caspian oil and gas pipelines that could channel Kazakh oil and gas into the east-to-west energy corridor, substantial talks to start building a seabed pipeline to connect Kazakh oil to the BTC have been put on hold. Rather, Kazakhstan will transport oil from Aktau to Baku by existing tankers and a new large-capacity tanker fleet. The position of Kazakhstan has been that strategic partnerships with the United States, Russia, and China are all necessary and that Kazakhstan would not pursue a special mission as the regional leader to promote the east - west energy corridor. Furthermore, slow progress and disagreements in the Kashagan project make the Kazakh political leadership reluctant to commit the bulk of Kazakh oil to the BTC pipeline.

Second, the risks inherent in relying solely on the CPC were highlighted in 2005, when Russia blocked the expansion of the pipeline and Tengizchevroil JV had to plan for more costly transportation by rail. However, following the agreement in March 2006 between Russia and China to build a gas pipeline and continuing talks to build a pipeline carrying oil from Siberia to China, there were concerns raised by oil analysts whether enough oil exists in Siberian fields to satisfy both Chinese and Japanese pipelines. Russia wanted to ensure its strategic partnership with Kazakhstan not only to increase energy cooperation between Kazakhstan and both Russia and China, but also to secure more gas from Central Asia to the Russian-controlled pipeline system. ${ }^{32}$ Thus, Kazakhstan and Russia agreed to widen the capacity of the CPC, which meant that in the absence of new oil production from Kashagan, the next eight years of oil production would flow through the CPC. ${ }^{33}$

\footnotetext{
${ }^{30}$ Costing approximately $\$ 29$ billion to develop, the Kashagan field has presented particular challenges for the Agip KCO. Kashagan contains a high proportion of natural gas under very high pressure, the oil contains large quantities of sulphur, and the offshore platforms require construction that can withstand the extreme weather fluctuations in the northern Caspian Sea area.

${ }^{31}$ When in March 2003, British Gas reached an agreement with China's CNOOC and Sinopec to sell them each a half of its share in Agip KCO, most of the partners in Agip KCO exercised their rights of pre-emption, whereby they were entitled to purchase BG's stake at the same price offered by the Chinese ('The Dragon Tucks In-Chinese Companies Abroad', Economist, 2 July 2005, pp. 67-69). Thus, Western oil companies demonstrated a commitment to the east-to-west energy corridor by stopping Chinese participation, which might divert oil volumes into the Kazakhstan-China pipeline.

${ }^{32}$ The two branches of the Central Asia-Centre (CAC) gas pipeline, the main gas export pipeline from Central Asia, particularly from Turkmenistan, meet in the south-western Kazakh city of Beyneu before crossing into Russia at Alexandrov Gay and feeding into the Russian pipeline system.

${ }^{33}$ For Kazakhstan's oil production see Energy Information Administration, Country Analysis Briefs, Kazakhstan, October 2006, available at: http:/www.eia.doe.gov/emeu/cabs/Kazakhstan/Full.html, accessed March 2007.
} 
Third, lacking in trained military personnel and technology, Kazakhstan is firmly in favour of strategic partnerships with Russia, China, and the United States for security purposes. Thus, Kazakhstan is pursuing a multi-vector foreign policy aimed at not favouring any power at the expense of the other. For example, Kazakhstan is a member of both the Shanghai Cooperation Organisation (SCO) and the Collective Security Treaty Organisation (CSTO) and has participated in the NATO-sponsored defence cooperation initiative, Partnership for Peace (PfP), since $1994 .{ }^{34}$ Although former Kazakh Defence Minister Mukhtar Altynbaev clearly expressed that 'Kazakhstan does not have the objective of joining NATO', the country wants to promote strategic security in the Central Asian region with the alliance (Bordonaro 2006). Kazakhstan deliberately balances the influence of Russia and China with that of the United States, while avoiding a bold pro-Western policy, given the geopolitical imperatives of living between these two strong neighbours.

\section{Internal politics, national identity and foreign policy: pragmatism of President Nazarbayev}

Underlying the pragmatism of Kazakhstan's leadership in following its multi-vector foreign policy is a conception of national identity that has been nurtured by President Nazarbayev to legitimise his authoritarian rule and consolidate his power. For example, according to Cummings, the leadership has used foreign policy to legitimise its rule and reshape national identity, given that 'the relationship between national identity and foreign policy is symbiotic' (Cummings 2003, pp. 149-51). Similarly, Schatz has argued that in post-Soviet Kazakhstan, the meaning of national identity has been 'accommodated through institutional crafting' as a way of preserving stability and ensuring national unity of the multi-ethnic people of Kazakhstan in the state and nation-building process (Schatz 2004, p. xxiii).

In the early years of independence, Kazakhstan was experiencing some significant internal disarray that posed a challenge to the stability of Nazarbayev's rule. ${ }^{35}$ Kazakhstan's economic problems worsened following the disintegration of the Ruble zone in 1992-93. ${ }^{36}$ In 1994, the government launched a series of economic programmes to overcome hyperinflation. As a result of the government's efforts to curb inflation by reducing public spending and raising prices, cash-strapped state enterprises stopped paying their employees and suppliers. Wage and pension arrears became an extremely acute problem in Kazakhstan, reaching $40 \%$ of the country's GDP by $1997 .^{37}$ Moreover, after the disintegration of the USSR, the Russian population of western and northern Kazakhstan's cities, most of which had been built as Russian military bases, began organised movements demanding political autonomy from Almaty. Close physical proximity to the Russian border made these potentially separatist claims alarming. The Kazakhstan government perceived Russian separatism

\footnotetext{
${ }^{34}$ In 2002 Kazakhstan joined the PfP Planning and Review Process (PARP).

${ }^{35}$ For detailed information on Kazakhstan's socioeconomic problems and political unrest see Luong (2000, pp. 94-98).

${ }^{36}$ The inflation rate reached $70 \%$ during the first two months after the introduction of the national currency 'Tenge' in Kazakhstan in 1994 (Kiyanitsa 1994).

37،Supplement on Kazakhstan', Financial Times, 17 June 1998, p. 2.
} 
as a real threat to the integrity of the state. Thus, the threat of social explosion highlighted the need to preserve ethnic peace and economic stability in Kazakhstan between 1992 and $1998 .^{38}$

As part of the process of consolidating his own authoritarian power, President Nazarbayev ruled by decree without a parliament between 1993 and 1995. In December 1993, he forced the self-dissolution of the Soviet-era parliament and in 1995 dissolved the second parliament using the irregularities of the 1994 elections as an excuse. Between 1992 and 1998, the country had three constitutions, three parliaments, and three prime ministers. During this period Nazarbayev consistently promoted the idea of a strong interventionist state in search of the capital necessary to revive its economy. ${ }^{39}$ The leadership were particularly concerned by the impact of political instability on their strategy for economic development centred on oil and made frequent changes of oil officials within the government. This demonstrated the weakening of the position of oil officials and prominent political figures in the government vis-à-vis President's Nazarbayev. Thus, the geopolitical context of oil and gas projects, reinforced by authoritarian rule, did not allow for an alternative in foreign policy discourse and the state-building process other than the pragmatism of President Nazarbayev.

Central to the leadership's 'crafting' of national identity and consolidating its power was its management of clan rivalries. This was especially important in the first decade of Nazarbayev's rule and resulted in a further bolstering of his position and a significant weakening of the potential for internal politics to have any strong influence on the making of foreign policy. President Nazarbayev's pragmatism involved the reconstructing of the meanings of clan identities, as he successfully managed inter-clan divisions by means of clan balancing and exerting his authoritarian presidential power (Schatz 2004, pp. 95-112). There are three main clans or hordes (zhuz) in Kazakhstan. The Elder Clan (Ulu Zhuz, Greater Horde) traditionally inhabited south and southeastern Kazakhstan, while the Middle Clan (Orta Zhuz) was settled in the north and north-east. The Younger Clan (Kishi Zhuz) was mostly in the western region around the Caspian Sea. After the demise of the Soviet Union, Younger Clan Kazakhs had relatively little involvement in post-Soviet state-building, the Middle Clan occupied most of the technical professions with their higher degree of Russification, and the Elder Clan remained politically predominant, given its proximity to Almaty. President Nazarbayev is a member of the Elder Clan from the village of Chemolgan.

During the Soviet period, persistent shortages under the highly centralised economic system transformed clan identity in an unintended way, and clan networks continued to be instrumental in accessing otherwise unattainable goods in the shortage economy (Schatz 2004, pp. 21-71). The strength of clan networks in the Soviet era continued into the period of independent Kazakhstan, which in turn helped President Nazarbayev to consolidate his power in a hierarchical administrative structure by creating privileged nodes of access in domestic politics for his clan-based network (Luong 2004, pp. 12-14). For example, Nurtai Abykaev (the president's closest

\footnotetext{
${ }^{38}$ For a detailed discussion of ethnic problems in Kazakhstan, see Olcott (2002, pp. 51-86).

${ }^{39}$ For detailed information on the shift of more power to the President see Olcott (2002, pp. 112-23) and for the leading reference guide to the elite in Kazakhstan see Ashimbaev (2001).
} 
advisor), Akhmetzhan Esimov (deputy prime minister from 1996 to 1998, and chair of the president's administration from mid-1998), Al'nur Muasev (director of the Committee on National Security, successor to the KGB), Kasymzhomart Tokaev (Minister of Foreign Affairs), Mukhtar Abliazov (Minister of Energy, Industry and Trade), Omirbek Baigel'di (chair of the Senate), and Ltynbek Sarsanbaev (director of the National Agency on Press Affairs and Mass Information) were the leading members of the government from the Elder Clan favoured by President Nazarbayev in the late 1990s (Schatz 2004, p. 99).

However, although President Nazarbayev appointed members of the Elder Clan to key positions in the government, he applied a pragmatic strategy that accommodated 'clan balancing' and 'clan clientielism' simultaneously. Conflict between various clan networks, including the three main clans, emerged in a distinct political form in relation to the distribution of resources during mass privatisation and the growth of foreign direct investment in the oil and gas sectors. Although clan affiliations were not emphasised the second tier of privatisation strengthened the personal fortunes of the Kazakh elite, and foreign direct investment was kept exclusively under the control of President Nazarbayev by making use of clan networks and exploiting rivalries (Olcott 2002, pp. 136-48; Schatz 2004, pp. 113-35).

Rather than a multinational identity or a strong Kazakh national identity, 'clan politics is always scaled at multiple levels and kinship networks are activated in differently scaled contexts at different contextual moments' (Schatz 2004, p. 98). The Kazakh leadership aimed to leverage clan competition to secure political stability and regime legitimisation. While the state suppressed clan clientielism at the regional (oblast') level in order to control regional power bases that might undermine the political dominance of the Elder Clan, clan loyalty was activated in different contexts. For example, the loyalty of the Middle Clan Kazakhs was particularly critical when the separatist inclinations of non-Kazakhs in the northern oblasts presented a potential threat to Kazakhstan's territorial integrity. At this time, the first prime minister, an ethnic Slav, Sergei Tereschenko (1992-94) was replaced by Akezhan Kazhegeldin (1994-97) from the Middle Clan (Schatz 2004, p. 101), and more generally also, President Nazarbayev ensured that top elite appointments contained a considerable share of Middle Clan members.

Similarly, when foreign investment accelerated in the western regions, where Kazakhstan's largest oil and gas resources are located, representation of the Younger Clan elite in the government was ensured by the appointment of Nurlan Balgimbaev as prime minister in 1997. Nevertheless, President Nazarbayev succeeded in consolidating the management of all major investment contracts under his exclusive control and thwarting any attempt to form a regional power base among rival clan elites. $^{40}$

\footnotetext{
${ }^{40}$ There have been three periods of opposition in Kazakhstan since 1991. In the early 1990s nationalist, communist and liberal were small opposition groups that had little support within both the Elder Clan and emerging business groups. The second period, starting in 1996, included some highranking government officials. However, they had almost no support from the business elite, which prospered under the patronage of President Nazarbayev. Prime Minister Akezhan Kazhegeldin (1994-97) was the exception. He made his personal fortune from privatisation and founded the Republican People's Party of Kazakhstan in 1999. Kazhegeldin later was exiled and prosecuted for
} 
In general however, the turnover and social profiles of government members have not exerted any considerable influence on the foreign policy direction of Kazakhstan. For example, the second Prime Minister of Kazakhstan, Akezhan Kazhegeldin from the Middle Clan Kazakhs (1994-97), strengthened his position with the help of his connections to the Soviet era military and security elite by favouring Russian access to Kazakhstan's under-priced contracts for the export of metallurgy resources. However, despite Kazhegeldin's close ties to Russia, there is no evidence of a direct link between his pro-Russian orientation and Kazakhstan's heavy dependence on Russia, particularly between 1991 and $1997 .{ }^{41}$ Although Kazhegeldin was removed mainly to undermine his increasing domestic power base, which was supported by the emerging business elite, the appointment of Nurlan Balgimbaev (from the Younger Clan Kazakhs) aimed not only at representing the Younger Clan in the clan balancing politics of President Nazarbayev, but also at utilising his expertise and significant experience in the oil industry. Indeed, Balgimbaev's family had worked in Kazakhstan's oil industry for several generations and he was associated with Tengizchevroil since its inception before his appointments in the Kazakh government as the Minister of Oil and Gas in October 1994, and as head of Kazakhoil when the ministry was dissolved. Moreover, when tensions with Russia finally abated after 1997, both over demarcation of the Caspian Sea and delays in exporting oil from the Tengizchevroil via the CPC pipeline, there emerged more room for flexibility in foreign policy-making in order to realise Kazakhstan's long-term strategic goal of building new pipelines bypassing Russia. Thus, rather than a clearly observed influence of key personalities on foreign policy orientation, the authoritarian rule of President Nazarbayev and his pragmatism related to the geopolitics of oil and gas took centre stage in Kazakhstan's foreign policy discourse. ${ }^{42}$

Thus President Nazarbayev's quest for legitimacy exploited clan identity to consolidate his power as well as to mask his authoritarian rule in domestic politics. The Kazakh leadership successfully managed 'clan balancing' by the circulation of

corruption. The third period started in 2001 when the Democratic Choice of Kazakhstan was established. The movement split into radical and moderate opposition. In January 2002 the moderates (Oraz Zhandosov, Alikhan Baimenov and Bulot Abilov) formed the Ak Zhol (Bright Path). The opposition of Ak Zhol became questionable when Oraz Zhandosov was appointed as presidential aide in January 2003. The radicals were Galymzhan Zhakiyanov and Mukhtar Ablyazov who were jailed in late 2002 on charges of corruption.

${ }^{41}$ For details of Kazhegeldin's close ties to Russia see Olcott (2002, pp. 161-63).

${ }^{42}$ For example, although the head of the Kazakhstan Centre-Right Atameken Party (KPPP) Yerzhan Dosmukhamedov argued that Kazakhstan should align its foreign policy with the US and the other Western powers and abandon its current strategy of balancing the influence of Russia, China and the West, he did not directly criticise the president. Kazakhstan-based analysts, in fact, emphasised that the new party enjoys government backing and it is unlikely to grow into a serious opposition group. The KPPP was established in January 2007 by four political groups (the right-wing Atameken, the Sootechestvennik Party, the Alash People's Party and the National Federation of Kazak Farmers which were not registered officially in the party system). The new party headed by Yerzhan Dosmukhamedov, an advisor to Timur Kulibayev (the president's son-in-law) and a former vice president of KazMunaiGaz, explained that the party's philosophy is based on 'the market economy and consequently democracy' rather than other personality-centred political parties in Kazakhstan (Kucera 2006; 'Second Big Political Alliance Emerges', Institute for War and Peace Reporting, 16 January 2007). 
elites that benefited from his patronage (Schatz 2004, p. 104). In recent years however, the influence of clan identity has begun to decline. According to a report on 'influence groups' in domestic politics by the Almaty-based Eurasian Centre for Political Research and Epicentre Agency for Social Technologies in 2005, 'current influence groups are formed along the principle of personal loyalty and affiliation and interact with each other on the basis of hard, pragmatic interests'. The report identified four major influence groups: the first, around Darigha Nazarbayeva, the president's eldest daughter, and her husband Rakhat Aliev, who control significant media assets but lack major assets in the raw-materials sector; the second around Timur Kulibaev, another son-in-law of the president who controls major assets in the raw materials sector; the third around Nurzhan Subkhanberdin, the President of Kazkommertzbank group, Kazakhstan's largest private financial institution, which also has business links with Timur Kulibaev; and the fourth, the so-called 'Eurasian' group involving businessmen Aleksnadr Maskevich, Patokh Shodiev and Alidzhon Ibragimov, who are all non-ethnic Kazakh and control major assets in the metal industry (Kimmage 2006a).

This trend indicates that President Nazarbayev's balancing tactics may be shifting in focus from clans to interest groups, without implying any decline in his authoritarian powers. Nevertheless, the continuing influence of the clans may have been underestimated by the report. In February 2006 the murder of Altynbek Sarsenbaev, who was twice a minister, an ally of President Nazarbayev before joining the opposition in 2003 and co-chairman of the opposition party Naghyz Ak Zhol (True Bright Path), was interpreted in the media as indicating an emerging conflict of elites and the beginning of a succession struggle for the presidency among various clans. ${ }^{43}$ Thus, it may be that President Nazarbayev's strategy for maintaining his authoritarian rule will continue to involve 'clan balancing' while the aforementioned influence groups compete for influence over him rather than over the electorate.

Moreover, the most recent change in the Kazakh government, in fact, seems to confirm the continuity of his authoritarian rule and pragmatism in foreign policy making. Although former Prime Minister Danial Akhmetov had been a loyal supporter of the president and an influential person in the energy sector with close relations to Russia, the multi-vector foreign policy of Kazakhstan prevailed (Yermukanov 2005b). Despite the smooth and intensifying economic relations with Russia during Akhmetov's administration, Kazakhstan has continued its foreign policy of not favouring any power at the expense of the other. For example, when Kazakhstan and the European Union signed a memorandum of understanding on energy in December 2006, President Nazarbayev emphasised the multi-directional orientation of Kazakh foreign policy, stating that 'any route which is feasible and efficient for the transfer of Kazakh hydrocarbons will be thoroughly considered... Kazakhstan will still probably be using the Russian network to the Baltic ports ... also discussed the further extension of the Baku-Tbilisi-Ceyhan (BTC) pipeline'

\footnotetext{
${ }^{43}$ See, for example, the views of Erlan Akin, a political analyst, in the newspaper Respublika, 24 February 2006, and Bakhtiyar Sagandykov in the bulletin of the political news agency APN, 26 February 2006. See also Kimmage (2006a).
} 
(Kimmage 2006b). Likewise the new Foreign Minister Marat Tazhin confirmed that Kazakhstan would continue 'to pursue a multi-vector policy governed by the economic and political interests of our country' (Lillis 2007). While the new Prime Minister Karim Masimov has important experience in foreign trade and is known to speak Chinese fluently, it is hard to tell whether Kazakhstan would shift its foreign policy favouring closer relations with China. In fact, Kazakhstan has always been sensitive about China's influence in the region and fearful of the perceived threat of Chinese migration (Thoenes 1996c; Yermukanov 2004, 2005a; Alles 2005, p. 134). ${ }^{44}$ Similarly, the consolidation of political parties demonstrated the continuity of the balancing of clan interests, which in turn aimed to ensure President Nazarbayev's power base during his last term in office. ${ }^{45}$

\section{Conclusions}

While 'the clans and the state construct each other in an ongoing dialectic', political continuity and change in Kazakhstan has essentially been effected by a process of state-managed clan balancing (Schatz 2004, p. 163). The authoritarian strategy of state building has created a relational national identity, which has further facilitated the multi-vector foreign policy (Cummings 2003, pp. 144-49). The clan balancing strategy has prevented the emergence of domestic political interests as a strong influence on foreign policy. Rather, foreign policy has been instrumental in bolstering the personal prestige of the president and the gaining of recognition for the state of Kazakhstan by the international community. Although a 'Kazakhisation' of foreign policy, in which ethnic Kazakhs have been appointed to most of the embassies and key posts in the Ministry of Foreign Affairs, has been observed, this article has argued that geopolitics and pragmatism would allow a limited role for the national identity and interest politics (whether through clan or interest group networks) in foreign policy making in Kazakhstan.

Likewise the question of whether Kazakhstan is looking East or West in its foreign policy orientation should be answered considering the persistence of geopolitics and

\footnotetext{
${ }^{44}$ Concerns have been aggravated by Chinese oil companies using the lack of qualified oil specialists as an excuse to bring large numbers of Chinese workers to work in Kazakhstan. The Kazakhstan Migration Agency cannot provide accurate numbers of how many Chinese live in Kazakhstan illegally in the cities of Pavlodar, Aktobe and Semey. Furthermore, President Nazarbayev does not want to see a higher degree of social intercourse between Kazakh Dungans (Chinese-speaking Muslims are called Dungans in Central Asia) and China.

${ }^{45}$ For example, in October 2006 Alikhan Baimenov, head of the Ak Zhol (Bright Path) Party, who was a presidential candidate in the December 2005 election, opted to be in the parliament. His preference to be a parliament member reversed the course of his party since the Ak Zhol refused to be in the parliament after the 2004 parliamentary election to protest the flawed polls. In fact, the Ak Zhol party split and the faction called themselves Nagyz Ak Zhol (True Bright Path) Party which takes a more sceptical stand against the president. Furthermore, in July 2006 the pro-presidential Asar Party led by Dariga Nazarbayeva (the president's elder daughter) merged with President Nazarbayev's Otan (Fatherland) Party and changed its name to Nur-Otan Party. Similarly in December 2006, the other pro-presidential Civic Party and Agrarian Party voted to join Nur-Otan Party (Lillis 2006; Kennedy 2007). These developments further suggest that rather than establishing an independent power base, influence groups and clan elites articulate their interests in the current regime and promote a single party model reinforcing Nazarbayev's authoritarian power in domestic politics.
} 
pragmatism in foreign policy making. Kazakhstan's geopolitical imperatives force the country to maintain good relations with Russia and China as well as with the United States and the European Union, as counterbalancing partners. The Kazakhstan government is likely to continue its strategy of including Russia and China in energy cooperation. Accordingly, Kazakhstan's commitment to the east-to-west energy corridor is important for the emerging concept of energy security, in terms of both tapping new energy supplies and diversifying long-distance, cross-border pipeline routes. In fact, Kazakhstan's persistent policy not to favour any power at the expense of others and its desire to secure multiple pipelines going both east and west would facilitate such an approach.

\section{Bilkent University}

\section{References}

Alles, E. (2005) 'The Chinese-speaking Muslims (Dungans) of Central Asia: A Case of Multiple Identities in a Changing Context', Asian Ethnicity, 6, 2, June.

Ashimbaev, D.R. (2001) Kto est' kto v Kazakhstane (Almaty, Credo).

Berke, R.L. (1993) 'Prodded by Gore, Kazakhstan Signs Arms Accord', New York Times, 14 December.

Blank, S. (2005) 'PetroKaz: China’s Difficult Search for Central Asian Energy', China Brief, 5, 23, pp. $5-7$.

Bordonaro, F. (2006) 'Kazakhstan and the New Great Game', Asia Times, 10 March.

Buckley, N. \& Hoyos, C. (2005) 'Pipe Dreams Blighted by Ice and Taxes', Financial Times, 3 December.

Bukkvoll, T. (2004) 'Astana's Privatised Independence: Private and National Interests in the Foreign Policy of Nursultan Nazarbayev', Nationalities Papers, 32, 3, September.

Corzine, R. (1997) 'China a Counter-weight to Russia's Influence', Financial Times, 23 July.

Croissant, C.M. \& Croissant, M.P. (1999) 'The Legal Status of the Caspian Sea: Conflict and Compromise', in Croissant, M.P. \& Aras, B. (eds) (1999) Oil and Geopolitics in the Caspian Sea Region (Westport, CT, Praeger Publications).

Cummings, S.N. (2003) 'Eurasian Bridge or Murky Waters between East and West? Ideas, Identity and Output in Kazakhstan's Foreign Policy', Journal of Communist Studies and Transition Politics, 19, 3, September.

Economist Intelligence Unit (1997) Country Profile Kazakhstan 1996 (London).

Economist Intelligence Unit (1998) Country Profile Kazakhstan, 1997 (London).

Energy Information Administration (1997) 'Country Analysis Briefs: Caspian Sea Region', available at: http://www.eia.doe.gov/emeu/cabs/caspconf.html, accessed December 1998.

Forsythe, R. (1996) The Politics of Oil in the Caucasus and Central Asia (Oxford, Oxford University Press).

Freeland, C. \& Thoenes, S. (1996) 'Caspian Pipeline Deal is Signed', Financial Times, 27 April.

Gorst, I. \& Tsui, E. (2005) 'Kazakhstan Flexes Muscles over Petrokaz', Financial Times, 4 October.

Ipek, P. (2004) 'Azerbaijan Government's Policy on Multinational Corporations and Change of Power in Azerbaijan', conference paper presented at 5th Annual Conference of Central Eurasian Studies Society, Bloomington, Indiana, $14-17$ October.

Jonson, L. (1998) Russia in Central Asia: A New Web of Relations (London, Royal Institute of International Affairs).

Kennedy, R. (2007) 'Consolidation of Political Parties in Kazakhstan Strengthens President's Hand', Central Asia Caucasus Analyst, 24 January.

Kimmage, D. (2006a) 'Kazakhstan: A Shaken System', Eurasia Insight, 5 March.

Kimmage, D. (2006b) 'Kazakhstan: Democracy, Energy, and Ambiguity', Eurasia Insight, 9 December.

Kiyanitsa, V. (1994) 'Kazakhstan on the Verge of Hyperinflation', Moscow News, 25 February.

Kononovich, Y. (2004) 'Key Factor of Modernization', Kazakhstanskava Pravda, 15 December.

Kucera, J. (2006) 'Kazakhstan: A New Political Party Borrows from Western Right', Eurasia Insight, 30 October. 
LeVine, S. (1994) 'Moscow Pressures its Neighbors to Share their Oil and Gas Revenues', Washington Post, 18 March.

LeVine, S. \& Curzine, R. (1994) 'Russia to get Share of Kazakhstan's Largest Gas Field', Financial Times, 8 November.

Lillis, J. (2006) 'Kazakhstan Experiences Political Shift', Eurasia Insight, 17 October.

Lillis, J. (2007) 'A Political Shake-up in Kazakhstan Strengthens Presidential Authority', Eurasia Insight, 12 January.

Luong, P.J. (2000) 'Kazakhstan: The Long-Term Costs of Short-Term Gains', in Ebel, R. \& Menon, R. (eds) (2000) Energy and conflict in Central Asia and the Caucasus (Lanham, MD, Rowman and Littlefield Publishers).

Luong, P.J. (2004) The Transformation of Central Asia: States and Societies from Soviet Rule to Independence (Ithaca, NY, Cornell University Press).

Olcott, M.B. (1995) 'Oil and Politics in Kazakhstan', Caspian Crossroads, 1, 1, Winter, available at: http://ourworld.compuserve.com/homepages/usazerb/casp.htm, accessed 19 May 2003.

Olcott, M.B. (2002) Kazakhstan: Unfulfilled Promise (Washington, DC, Carnegie Endowment for International Peace).

Petroleum Finance Company (1993) 'Pipeline Politics in Central Asia and Caucasus', Focus on Current Issues, May, pp. $21-22$.

Pomfret, R. (2005) 'Kazakhstan's Economy since Independence: Does the Oil Boom Offer a Second Chance for Sustainable Development?', Europe-Asia Studies, 57, 6, September.

Savin, I. (1998) The Dangerous Legacy of Soviet Nationalities Policy: Ethnic Identification in PostSoviet Kazakhstan (Chimkent, South-Kazakhstan Branch of Kazakhstan Academy of Sciences).

Schatz, E. (2000) 'The Politics of Multiple Identities: Lineage and Ethnicity in Kazakhstan', EuropeAsia Studies, 52, 3, May.

Schatz, E. (2004) Modern Clan Politics: The Power of 'Blood' in Kazakhstan and Beyond (Seattle, University of Washington Press).

Schofield, C. \& Pratt, M. (1996) 'Claims to the Caspian Sea', Jane's Intelligence Review, February.

Smith, J.R. (1992) 'Three Former Soviet Republics meet US Arms Terms', Washington Post, 27 April.

Thoenes, S. (1996a) 'Mobil to Buy 25 Percent of Big Asian Oilfield', Financial Times, 18 April.

Thoenes, S. (1996b) 'Kazakh Deal to Ease Blockage: Yeltsin to Sign Protocol on Construction of Dollars 2 Billion Pipeline', Financial Times, 27 April.

Thoenes, S. (1996c) 'Tough at Home, Tactful Away', Financial Times, 11 July.

Thoenes, S. (1996d) 'Way Cleared for Caspian Oil Pipeline', Financial Times, 18 November.

United Nations Industrial Development Organisation, UNIDO (1996) The Central Asian Republics, Industrial Development Review Volume I: Kazakhstan, Kyrgyz Republic and Tajikistan (Vienna, UNIDO).

US Department of State (1992) 'US-Kazakh Relations: Joint Declaration' Dispatch, 3, 21, May 25.

World Bank (1994) Statistical Handbook 1994, States of the Former USSR (Washington, DC, World Bank).

Yermukanov, M. (2004) 'China's Relations with Kazakhstan are Warming, but to what End?', Eurasia Daily Monitor, 1, 43, 1 July.

Yermukanov, M. (2005a) 'Sino-Kazakh Pipeline Project has Demographic, as well as Economic Dimensions', Eurasia Daily Monitor, 2, 75, 18 April.

Yermukanov, M. (2005b) 'Will Nazarbayev Sacrifice Government to Secure his Re-election?', Eurasia Daily Monitor, 11 July.

Zweig, D. \& Jianhai, B. (2005) 'China's Global Hunt for Energy', Foreign Affairs, 84, 5, September/ October. 